\title{
Design of A Small Scale Solar Powered Water Pumping System
}

\author{
Odesola I.F ${ }^{1}$ \\ ${ }^{1}$ Reader, Mechanical Engineering Deparment, \\ Faculty of Technology, University of Ibadan, \\ Oyo, Nigeria
}

\author{
Bright Samson ${ }^{2}$ \\ ${ }^{2}$ Mechanical Engineering Department, \\ Faculty of Technology, University of Ibadan \\ Oyo Nigeria
}

\begin{abstract}
An intense irradiation by the sun on the earth causes excessive evapotranspiration (loss of water), a factor that is unpleasant to farmlands, livestock and remote areas where people reside. This unpleasant situation can be used as an opportunity to provide enormous supply of water to these areas.

This work focuses on the design; fabrication and testing of water pump system powered by a solar photovoltaic (P.V) panel. Two 12V, 17AH battery was incorporated in the pump system to ensure storage and stability of power discharged. The system pumped water at an average of $30 \mathrm{~L} / \mathrm{min}$ within the hours of $1 \mathrm{pm}$ to $4 \mathrm{pm}$ at an hour interval. The pump was operated at different heads ranging from $3 \mathrm{~m}$ to $10 \mathrm{~m}$. The pump performed with an efficiency of $3.94 \%$ to $13.14 \%$. The power consumption was fixed at $0.373 \mathrm{kWh}$. The design and testing of the solar pump are presented in this work. The design can be used in rural and semi-urban areas with a moderate population and farms for irrigation practices where grid electricity is unavailable.
\end{abstract}

Keywords: Photovoltaic panel, solar pump.

\section{INTRODUCTION}

The need and demand for energy in different parts of the world is on the geometrical increase where different sources of energy are being harnessed to carry out work. Among all the energy sources, solar energy is gaining popularity in different parts of the world due to its daily availability and no pollution effects compared to fossil fuels. Solar energy is available in any part of the world, but the amount made available differs with respect to geographical locations, times and season [1]. The solar energy available at any particular geographical location is a measure of the solar irradiance falling on that location. Solar irradiance is the solar radiation intensity falling on a surface and is measured in $\mathrm{kW} / \mathrm{m}^{2}[2]$.

Solar energy is free, inexhaustible, yet harnessing it is a relatively new idea [1]. The sun is primary source of energy, and all form of energy on the earth is derived from it. Solar energy has the greatest potential of all the sources of renewable energy [7]. Many areas of design and inventions have found the use of solar energy very efficient and environmentally friendly compared to other energy sources. Solar energy, when converted into electrical energy, can be used to pump water from dug wells or streams to over-head tanks for storage or direct use on farmlands. Other methods used in pumping water include the electrical pump and fuel pumps. They all have their merits and demerits compared to the solar pump.

Solar pumping system is an integration of different components which generates power from the sun and operates on direct current to drive water from a particular source over a distance to another location. Solar pumping system requires the use of a solar photovoltaic panel to generate electricity from the sun to drive a pump which sucks up water from a particular source and discharges the water either to an overhead tank or piping within a long distance where water is needed. This is carried out in locations where electricity is unavailable. There are other methods to pump water for consumption and one of the best options is a photovoltaic (PV) pumping system. Solar water pumping provides a welcome alternative to fuel-burning generators for pumping water. Advantages of PV pumping systems include low operating cost, unattended operation, low maintenance, easy installation, and long life [3]. Solar pumping systems require no fuel. They are quiet, pollution free, efficient, simple, reliable and require little or no maintenance [4] [7]. Various facilities are available for automating the starting and stopping of water flow. Furthermore, solar pump can be available for small, medium and large-scale water requirements. The small system can cost little more than their fuel powered counterparts. Solar pumping is extremely efficient because maximum pumping power is available on intense sunny days when the water is needed most [5].

An intense irradiation by the sun on the earth causes excessive evapotranspiration (loss of water), a factor that is unpleasant to farmlands, livestock and remote areas where people reside. This intense irradiation being a menace can be used as an opportunity to provide large supply of water to the areas facing such crises. The use of a pump powered by a solar photovoltaic panel can be used to achieve this. This work focuses on the design, fabrication of a small- scale solar pump, testing and comparison with the electrical and fuel pumps.

\section{METHODOLOGY}

The design of a small-scale solar pump begins with the knowledge of daily water required, the solar irradiation of the location, the pumping time, the total head and power required 
to drive the water by the pump from the source to its 5. Pump Selection and Associated Power Requirement. destination [9].

2.1 The design processes

1. Calculating the water requirement..

2. Determining the solar irradiance.

3. Determining the flow rate for the pump.

4. Calculating the Total Dynamic Head (TDH) for the Pump.
6. Deciding pump power requirements.

7. Selecting the piping system to suit the design [8].

\subsection{The design calculations}

1. The chosen daily water required by an average person: $250 \mathrm{~L}-500 \mathrm{~L}$ per day.

Table 1: The solar irradiance for Ibadan:

\begin{tabular}{llllll}
\hline Month & $\begin{array}{l}\text { Air } \\
\text { temperature }\left({ }^{\mathbf{0}} \mathbf{C}\right)\end{array}$ & $\begin{array}{l}\text { Relative } \\
\text { Humidity } \\
(\boldsymbol{\%})\end{array}$ & $\begin{array}{l}\text { Daily } \\
\text { Radiation } \\
\left(\mathbf{K W h} / \mathbf{m}^{2} / \mathbf{d a y}\right)\end{array}$ & $\begin{array}{c}\text { solar } \\
\text { Pressure }(\mathbf{K P a})\end{array}$ & $\begin{array}{l}\text { Atmospheric } \\
\text { Temperature }\left({ }^{\mathbf{0}} \mathbf{C}\right)\end{array}$ \\
\hline January & 26.1 & 56.9 & 5.50 & 99.0 & 28.2 \\
February & 26.4 & 65.2 & 5.70 & 98.9 & 28.6 \\
March & 26.0 & 79.5 & 5.64 & 98.8 & 27.6 \\
April & 25.9 & 83.8 & 5.35 & 98.9 & 27.0 \\
May & 25.7 & 84.5 & 5.09 & 99.0 & 26.7 \\
June & 24.9 & 85.6 & 4.57 & 99.2 & 25.7 \\
July & 24.0 & 85.6 & 4.00 & 99.3 & 24.5 \\
August & 23.9 & 84.8 & 3.79 & 99.3 & 24.5 \\
September & 24.3 & 85.7 & 4.11 & 99.2 & 25.1 \\
October & 24.6 & 85.0 & 4.70 & 99.1 & 25.5 \\
November & 24.9 & 81.0 & 5.11 & 99.0 & 25.8 \\
December & 25.4 & 67.7 & 5.35 & 99.0 & 26.8 \\
\hline
\end{tabular}

\section{Source:}

http://eosweb.larc.nasa.gov/cgibin/sse/retscreen.cgi?email=rets\%40nrcan.gc.ca\&step=1\&lat=7.23982\&lon=3.59299\&submit=s ubmit [10]

\section{DETERMINING THE FLOW RATE OF THE} PUMP:

Water requirement in liters per second $=\frac{Q\left(\frac{l t r s}{d a y}\right)}{T * 3600}$ $\mathrm{Q}=\mathrm{A} * \mathrm{~V}$

Water requirement in liters per second $=\frac{Q\left(\frac{l t r s}{d a y}\right)}{T * 3600}$

$\mathrm{Q}_{1}=\frac{250}{4 * 3600}=0.0174 \mathrm{Ltrs} / \mathrm{s}$

$$
\begin{aligned}
& \mathrm{Q}_{2}=\frac{400}{4 * 3600}=0.0278 \mathrm{Ltrs} / \mathrm{s} \\
& \mathrm{Q}_{3}=\frac{500}{4 * 3600}=0.0374 \mathrm{Ltrs} / \mathrm{s}
\end{aligned}
$$

\section{TOTAL DYNAMIC HEAD (TDH) FOR THE PUMP:}

The calculated TDH for the pump ranged from $10 \mathrm{~m}$ to $14 \mathrm{~m}$. Using the $\mathrm{H}_{\mathrm{T}}=\mathrm{H}_{\mathrm{S}}+\mathrm{H}_{\mathrm{D}}$

Where: $H_{S}$ is the static head $=10-14 \mathrm{~m}$ and $1 \mathrm{~m}$ for Household usage and Irrigation respectively.

$\mathrm{H}_{\mathrm{D}}$ is the dynamic head.

$\mathrm{H}_{\mathrm{D}}$ from Darcy Weisbach equation:

$\mathrm{H}_{\mathrm{D}}=\mathrm{kV}^{2} / 2 \mathrm{~g}[9]$

Where:

$\mathrm{K}$ - loss coefficient

$\mathrm{V}$ - velocity of water in pipes

g- acceleration due to gravity [9].

\section{PUMP SELECTION AND ASSOCIATED POWER REQUIREMENT:}

Power required to pump the water for the flow rate and total head.

Power P (watts) $=\frac{Q \rho g H}{e f f}$.

After the power required by the pump was determined, the input power from the motor was determined.

Power of the D.C motor.

$\mathrm{P}=\mathrm{T} \omega$ where $\mathrm{T}$ is the torque produced from the shaft of the motor. And $\omega\left(\frac{r a d}{s}\right)$ is the angular velocity of the shaft rotation.

$\omega=\frac{2 \pi N}{60}$ where $\mathrm{N}$ is the shaft speed in rpm.

Static head chosen $=\max$ of $30 \mathrm{~m}$.

A power range of $15 \mathrm{~W}-80 \mathrm{~W}$ to drive the water from the source to the destination for an average of 4-hours of solar irradiation.

Maximum output power $=80 \mathrm{~W} * 4$ hours $=320 \mathrm{Watt}-$ hours. 


\subsection{DESIGN COMPONENTS}

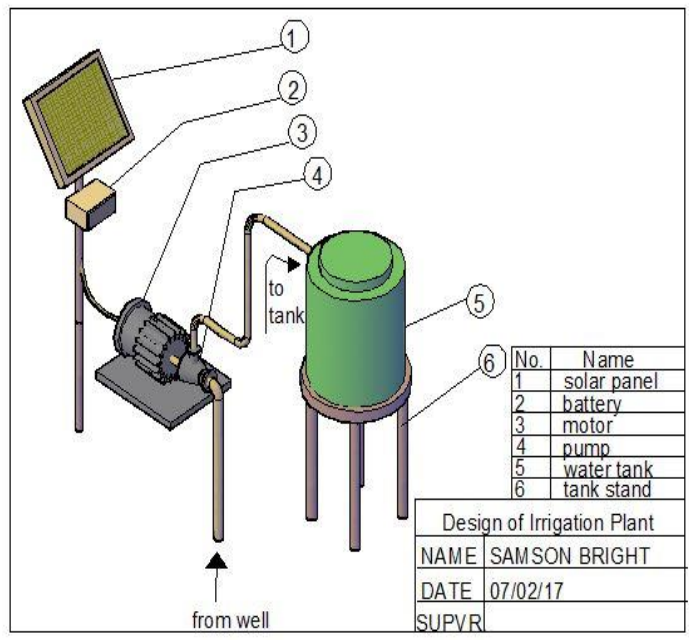

Fig 1: drawing of the solar pump system for domestic use.

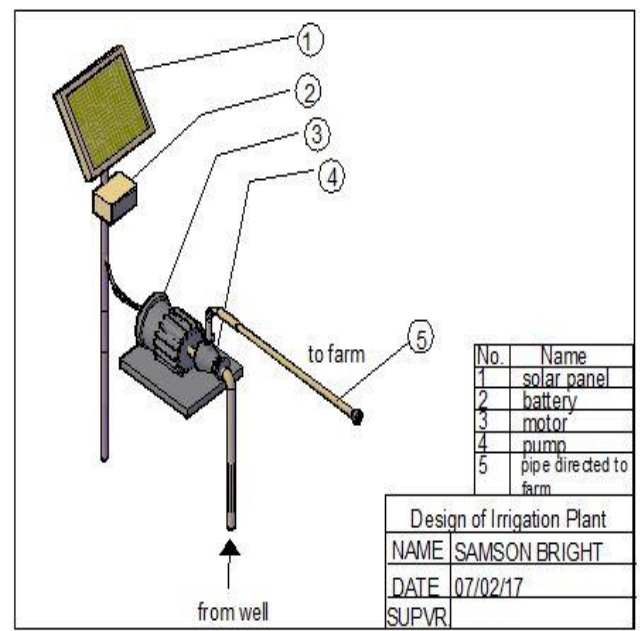

Fig 2: drawing of the solar pump system for irrigation

Table 2 : Components of the solar pump

\begin{tabular}{lll}
\hline S/NO & Irrigation & Domestic supply \\
\hline $\mathbf{1}$ & Solar P.V panel & Solar P.V panel \\
$\mathbf{2}$ & Charge controller & Charge controller \\
$\mathbf{3}$ & Electric motor & Electric motor \\
$\mathbf{4}$ & Motor shaft & Motor shaft \\
$\mathbf{5}$ & Centrifugal pump & Centrifugal pump \\
$\mathbf{6}$ & Suction pipe (P.V.C) & Suction pipe (P.V.C) \\
$\mathbf{7}$ & Water source & Water source \\
& ( a dam) & ( a well) \\
$\mathbf{8}$ & Delivery pipe (rubber pipe) & Delivery pipe (P.V.C) \\
$\mathbf{9}$ & Farmland & Overhead tank \\
\hline
\end{tabular}

Solar P.V panel $\rightarrow$ Charge controller $\rightarrow$ D.C Motor $\rightarrow$ Pump

\section{PUMP SPECIFICATIONS}

A pump is a machine for raising or transferring liquids or gases. A pump is a device that moves fluids (liquids or gases), or sometimes slurries, by mechanical action. The basic purpose of the pump is to transfer fluid from a lower level to a higher level.The pump model chosen for this work is: Italian Gold water pump QB60,

$\mathrm{Q}=30-351 \mathrm{tr} / \mathrm{min}$
$\mathrm{H}=5-30 \mathrm{~m}, \mathrm{~V}_{\text {input }}=220 \mathrm{~V}, \mathrm{I}_{\text {input }}=2.5 \mathrm{~A}$, Frequency $=$ $50 \mathrm{~Hz}$, Shaft speed on no load $=2850 \mathrm{rpm}$. Input power $\mathrm{P}_{\text {input }}=\mathrm{IV}=220 * 2.5=550 \mathrm{~W}$, Output power $=0.5 \mathrm{HP}=$ 373W.

Hence pump efficiency $=70 \%$.

$\mathrm{P}=\mathrm{T} \omega$, where $\omega=\frac{2 \pi N}{60}$ where $\mathrm{N}$ is the shaft speed in $\mathrm{rpm}$,

$\mathrm{T}$ is the shaft torque.

$\mathrm{P}=373 \mathrm{~W}, \mathrm{~N}=2850, \mathrm{~T}=\frac{373 * 60}{2 \pi * 2850}=1.3$. Shaft torque $=$ 1.3 .

With an output pump power of $320 \mathrm{~W}$ and efficiency of $70 \%$, input power for the pump $=457 \mathrm{~W}$.

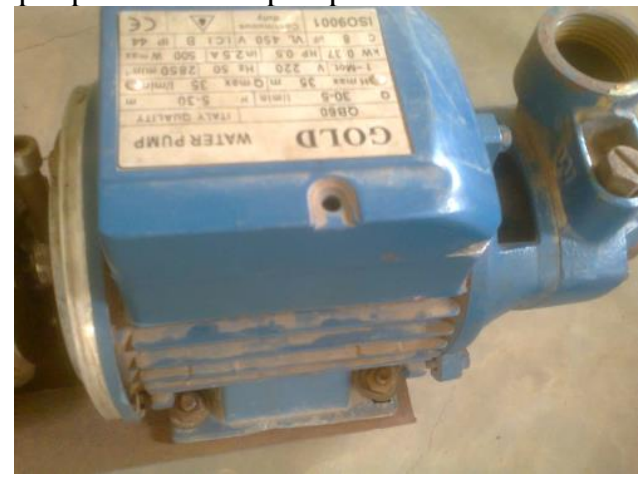

Fig 3 : The water pump

A D.C motor with a minimum output power of $457 \mathrm{~W}$ is required.

\section{C Motor}

The direct current (DC) motor is one of the first machines devised to convert electrical energy to mechanical power. A DC motor is any of a class of rotary electrical machines that converts direct current electrical power into mechanical power. This DC or direct current motor works on the principle that a current carrying conductor, placed in a magnetic field, it experiences a torque and has a tendency to move.

A D C motor of model, voltage- 12v, speed - $2500 \mathrm{rpm}$, current - 14 Amp and output - 250 watt

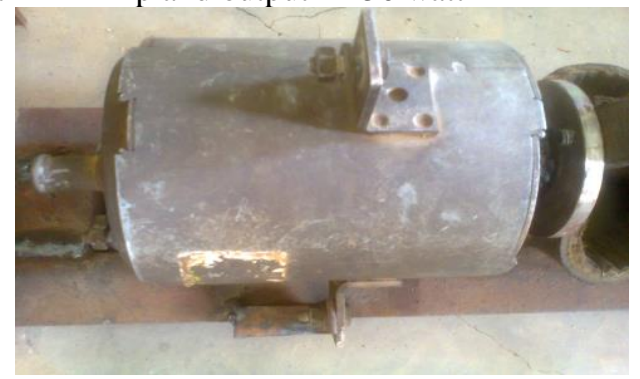

Fig 4: The d.c motor

\section{The Shaft Coupling}

The shaft coupling is made up of steel discs of diameter $80 \mathrm{~mm}$ and thickness $10 \mathrm{~mm}$ which transmit rotary motion and torque from the D.C motor to the pump. 


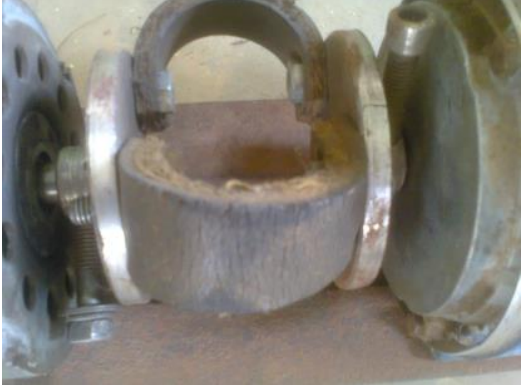

Fig 5: The shaft coupling

\section{The Battery}

Electrical storage batteries are often used in PV systems, as the demand for energy does not always coincide with its production. The electric current produced by PV panels during daylight hours charges the batteries, and the batteries in turn supply power to the pump anytime water is needed. The use of batteries spreads the pumping over a longer period of time by providing a steady

operating voltage to the DC motor of the pump [6]. The primary functions of a storage battery in a PV system includes:

energy storage capacity and autonomy, Voltage and Current Stabilization and Supply Surge Current.

The battery used for this design based on availability is two $12 \mathrm{~V}$ 17AHour Chitex deep cycle battery to be connected in parallel.

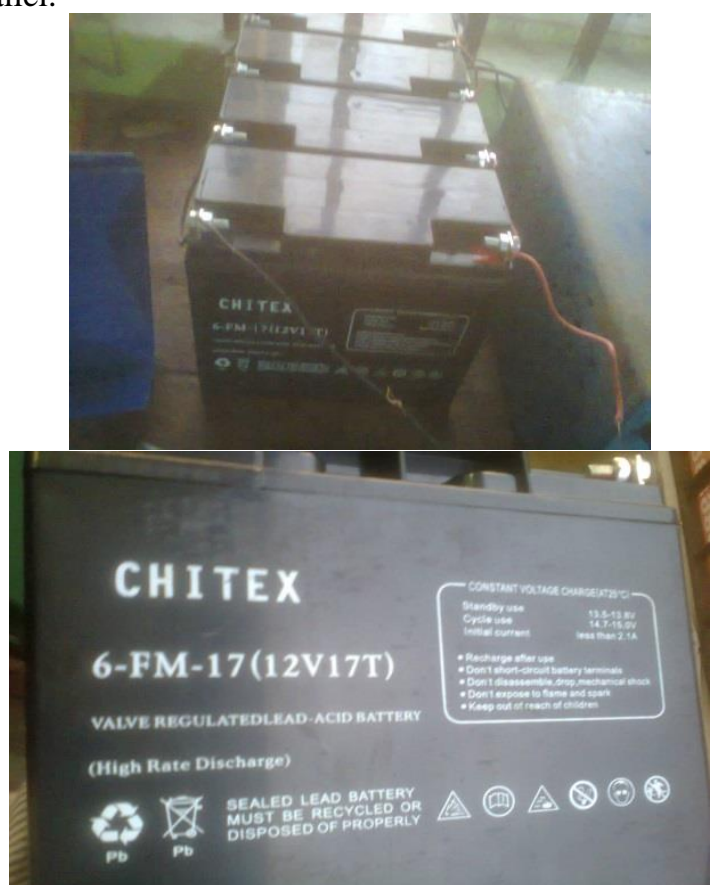

Fig 6: The deep cycle battery

\section{The Charge controller}

A solar charge controller or regulator is an essential component of every solar charging system. A charge controller may be used to power DC equipment with solar panels. The charge controller provides a regulated DC output and stores excess energy in a battery as well as monitoring the battery voltage to prevent under/overcharging. The main role of a controller is to protect and automate the charging of the battery.
The charge controller chosen for this work is a PWM controller.

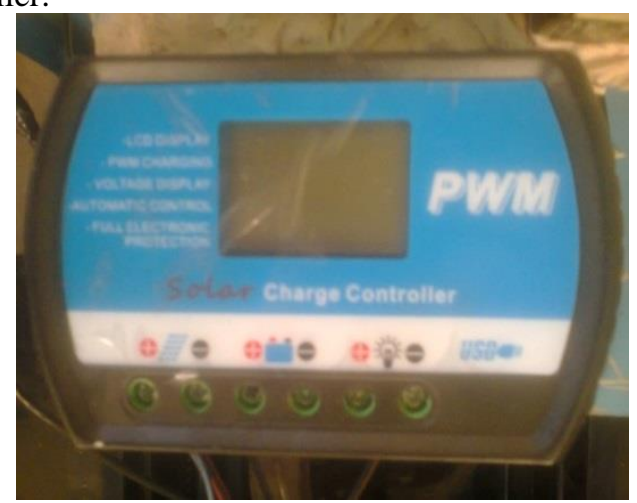

Fig 7: The PWM charge controller.

The P.V Panel

Photovoltaic module: the power source for solar pumping, have no moving parts, requires no maintenance and can last for decades [7].

The panels used for this design are two monocrystalline panels rated at $12 \mathrm{~V}, 30 \mathrm{Watts}$. The panels connected in series receive irradiation from the sun and releases voltage to the system. The panels charge the batteries.

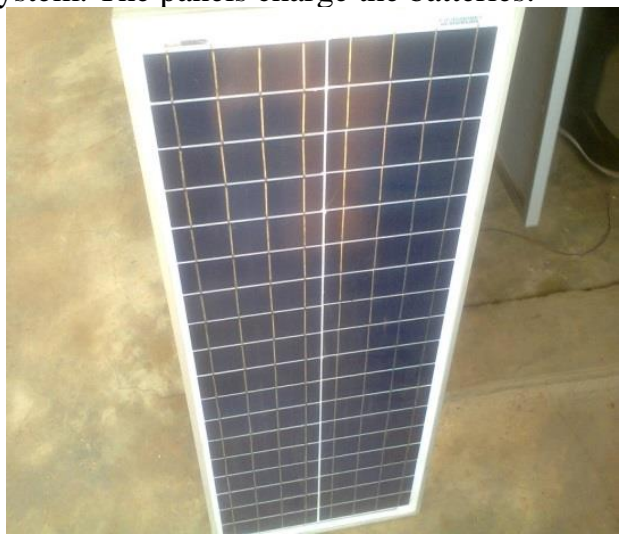

Fig 8: The Monocrystalline Solar P.V module.

The Casing

A steel casing with two handles made with dimension of $340 \mathrm{~mm} \times 340 \mathrm{~mm} \times 460 \mathrm{~mm}$, houses the motor, shaft, pump batteries and electrical systems.

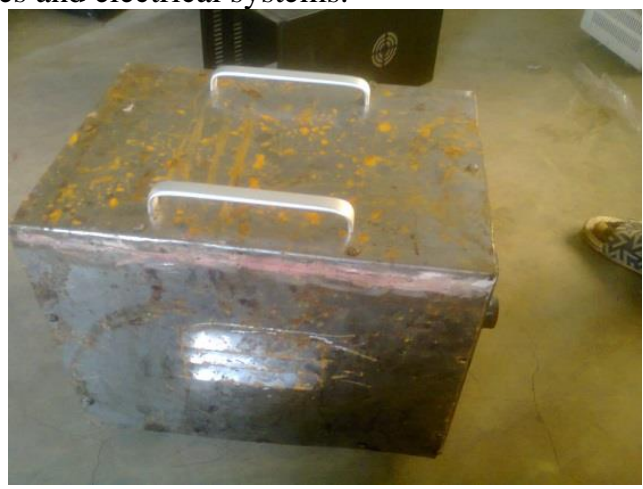

Fig 9: The casing.

The Electrical system.

The electrical system of the design comprises the:

- The wirings

- The indicators 

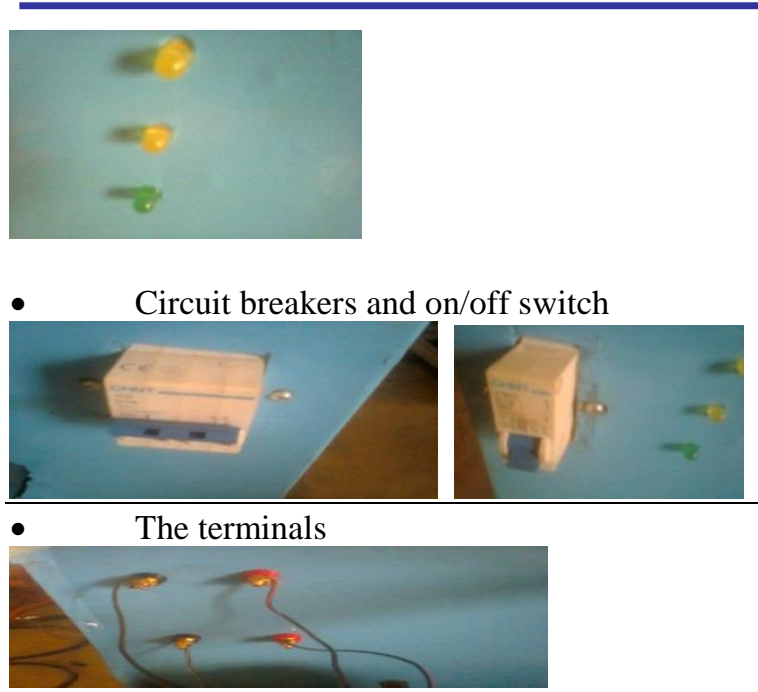

Fig 10: The electrical system

The total Assembly.
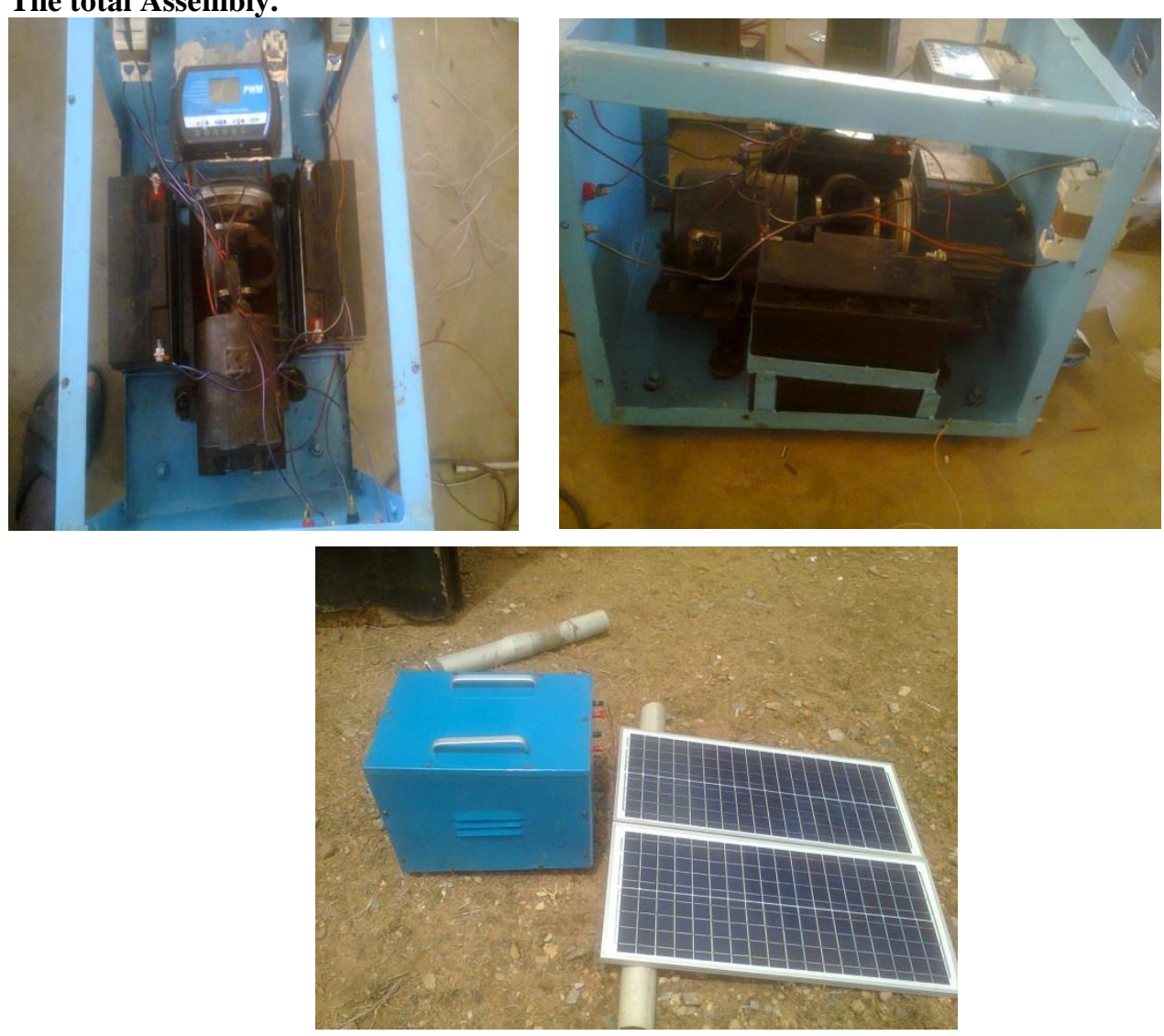

Fig 11: The total assembly

\subsection{TESTING}

The testing of the design was carried out at a well station at Fijabi Car-wash, along Ojoo/Iwo-road expressway in Ibadan with different heads ranging from $3 \mathrm{~m}$ to $10 \mathrm{~m}$ from the depth of the well at the water level between the hours of $1 \mathrm{pm}$ to $4 \mathrm{pm}$ at an hour interval. 


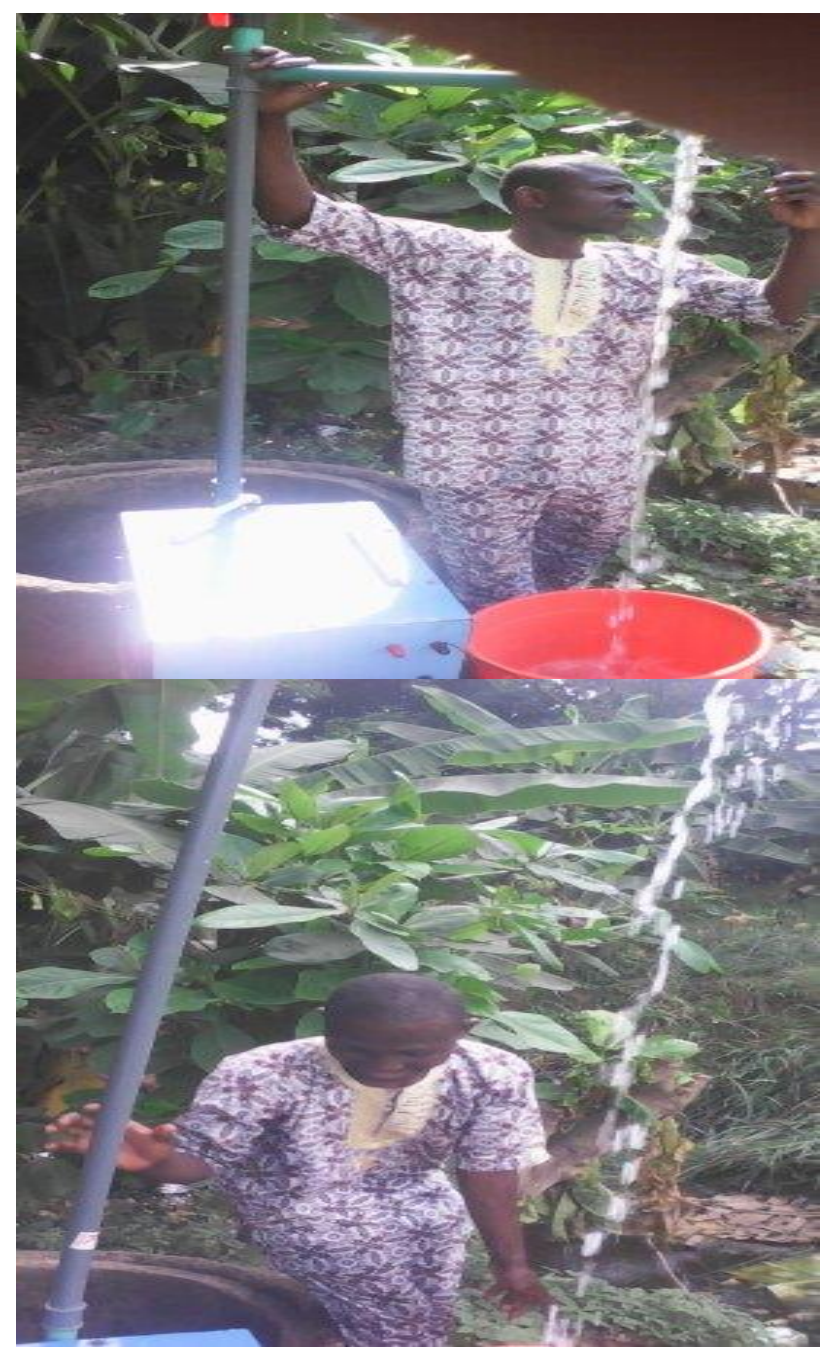

Fig 12: Testing of the design.

\subsection{RESULT AND DISCUSSION}

A fixed amount of 25litres to 30litres of water were obtained per minute at all the heads and time intervals totaling about $1500 \mathrm{~L}$ to $1800 \mathrm{~L}$ per hour. The output power of the system between 14 Watts to $49 \mathrm{Watts}$ conformed to the power calculated during the design, a pump efficiency ranging from $4 \%$ to $13 \%$. The solar pump consumed a constant power of $0.373 \mathrm{kWh}$.

The results of the amount of water pumped in liters per minute at different heads are shown in the table 3 below:

Table 3: Flow rates, Output power, Efficiencies and Energy consumption of Solar pump

\begin{tabular}{|c|c|c|c|c|c|c|c|c|}
\hline Head(m) & 1-2Pm & 2-3Pm & 3-4Pm & $\overline{Q\left(m^{3} / s\right)}$ & $\begin{array}{l}\text { Output } \\
\text { Power(watts) }\end{array}$ & Eff(\%) & Litres/H & $\begin{array}{l}\text { Energy } \\
\text { consumed } \\
\text { (kWh) }\end{array}$ \\
\hline 3 & 30 & 30 & 30 & 0.00050 & 14.70 & 3.94 & 1800 & 0.373 \\
\hline 4 & 30 & 30 & 25 & 0.00047 & 18.42 & 4.94 & 1700 & 0.373 \\
\hline 5 & 25 & 25 & 25 & 0.00042 & 20.58 & 5.52 & 1500 & 0.373 \\
\hline 10 & 30 & 30 & 30 & 0.00050 & 49.00 & 13.14 & 1800 & 0.373 \\
\hline
\end{tabular}


Power consumption of the pump was determined without the use of a panel tested at heads 3,4 and $5 \mathrm{~m}$.

Table 4: Output Power of pump without Panels.

\begin{tabular}{|c|c|c|c|c|}
\hline $\begin{array}{l}\text { Head } \\
\text { (m) }\end{array}$ & $\begin{array}{l}\text { Water pumped } \\
\text { (Ltrs/min) }\end{array}$ & $\begin{array}{l}\text { Average } \\
\text { Discharge } \\
\text { rate }\left(\mathbf{m}^{3} / \mathbf{s}\right) \\
\end{array}$ & $\begin{array}{l}\text { Output } \\
\text { (Watts) }\end{array}$ & Power \\
\hline 3 & 30 & 0.00050 & 14.72 & \\
\hline 4 & 25 & 0.00042 & 16.48 & \\
\hline 5 & 25 & 0.00042 & 20.60 & \\
\hline
\end{tabular}

The input power of the solar pump is $408 \mathrm{~W}$ to drive a $373 \mathrm{~W}$

powered by a $60 \mathrm{~W}$ panel. Where:

$\mathrm{Q}\left(\mathrm{m}^{3} / \mathrm{s}\right)=$ amount of water pumped.

Output power $\mathrm{P}($ watts $)=\frac{Q \rho g H}{e f f}$

The power consumed by the solar pump is $408 \mathrm{~W}$ and can

successfully pump between 1500 Ltrs to $1800 \mathrm{Ltrs}$

conveniently for an hour depending on the head and the

irradiation from the sun.

The result of the work parameters of four different fuel pump stations and three different electrical pump houses are given below:

Table 5: Results of work parameters of Fuel engines.

\begin{tabular}{|c|c|c|c|c|c|c|c|c|}
\hline Station & Head(m) & $\begin{array}{l}\text { Capacity } \\
\text { (litres) }\end{array}$ & $\begin{array}{l}\text { Engine } \\
\text { capacity } \\
\text { (watts) }\end{array}$ & $\begin{array}{l}\text { Pumping } \\
\text { time } \\
\text { (mins) }\end{array}$ & $\begin{array}{l}\text { Average } \\
\text { discharge } \\
\left(\mathrm{m}^{3} / \mathrm{s}\right)\end{array}$ & $\begin{array}{l}\text { Output } \\
\text { power } \\
\text { (Watts) }\end{array}$ & Eff $(\%)$ & $\begin{array}{l}\text { Energy } \\
\text { consumed } \\
(\mathbf{k W h})\end{array}$ \\
\hline
\end{tabular}

\begin{tabular}{lllllllll}
\hline M.M & 8 & 10000 & 5500 & 40 & 0.0042 & 329.6 & 5.9 & 3.67 \\
Fijabi & 8 & 500 & 2238 & 6 & 0.0014 & 109.9 & 4.9 & 0.224 \\
Orogun & 8 & 8000 & 1492 & 40 & 0.0033 & 259.0 & 17.35 & 0.995 \\
Texalon & 8 & 7300 & 2984 & 20 & 0.0061 & 478.7 & 16.04 & 0.995 \\
\hline
\end{tabular}

Table 6: Results of work parameters of electrical engines.

\begin{tabular}{|c|c|c|c|c|c|c|c|c|}
\hline Station & Head(m) & $\begin{array}{l}\text { Capacity } \\
\text { (litres) }\end{array}$ & $\begin{array}{l}\text { Engine } \\
\text { capacity } \\
\text { (watts) }\end{array}$ & $\begin{array}{l}\text { Pumping } \\
\text { time } \\
(\mathrm{mins})\end{array}$ & $\begin{array}{l}\text { Average } \\
\text { discharge } \\
\left(\mathrm{m}^{3} / \mathbf{s}\right)\end{array}$ & $\begin{array}{l}\text { Output } \\
\text { power } \\
\text { (Watts) }\end{array}$ & Eff (\%) & $\begin{array}{l}\text { Energy } \\
\text { consumed } \\
(\mathrm{kWh})\end{array}$ \\
\hline
\end{tabular}

\begin{tabular}{lccccccccc}
\hline Niyi & 15 & 1000 & 746 & 40 & 0.00042 & 61.8 & 8.3 & 0.497 \\
Carol & 20 & 3000 & 1865 & 120 & 0.00042 & 82.4 & 4.4 & 0.435 \\
Aaron & 16 & 3000 & 1119 & 60 & 0.00083 & 130.3 & 11.6 & 1.119 \\
\hline
\end{tabular}

A fixed amount of 25litres to 30litres of water were obtained per minute at all the heads and time intervals totaling to about $1500 \mathrm{~L}$ to $1800 \mathrm{~L}$ per hour for the solar pump. The output power of the system between 14Watts to 49Watts conformed to the power calculated during the design, a pump efficiency ranging from $4 \%$ to $13 \%$. Comparing the test results of the solar pump with the electric and the diesel pump from different houses and pump stations respectively, the diesel pump gave the greatest efficiency ranging from $6 \%$ to $17 \%$ while that of 
electric has an efficiency ranging from $8 \%$ to $11 \%$. The diesel pump has the greatest energy consumption ranging from $0.222 \mathrm{kWh}$ to $3.67 \mathrm{kWh}$, the electric pump consumed
$0.435 \mathrm{kWh}$ to $1.12 \mathrm{kWh}$, the solar pump consumed a constant power of $0.373 \mathrm{kWh}$

Table 7: COMPARATIVE ANALYSIS OF THE SOLAR, ELECTRICAL AND FUEL PUMPS.

\begin{tabular}{|c|c|c|c|}
\hline & SOLAR & ELECTRICAL & FUEL \\
\hline Power source & The all available sun & $\begin{array}{l}\text { Grid electricity where } \\
\text { available }\end{array}$ & Liquid fuel (diesel or petrol \\
\hline Maintenance & Little or no maintenance & $\begin{array}{l}\text { High cost of maintenance } \\
\text { due to burnt coil from } \\
\text { irregularities in power }\end{array}$ & $\begin{array}{l}\text { Constant purchase of fuel } \\
\text { and high servicing cost. }\end{array}$ \\
\hline
\end{tabular}

supply.

\begin{tabular}{|c|c|c|c|}
\hline Durability & Highly durable in years & $\begin{array}{l}\text { Moderately durable in } \\
\text { months }\end{array}$ & Highly durable in months \\
\hline Efficiency & $\begin{array}{l}\text { Moderately efficient between } \\
4-13 \%\end{array}$ & $\begin{array}{l}\text { Efficient only with a good } \\
\text { power supply between } 8- \\
11 \%\end{array}$ & $\begin{array}{l}\text { Highly efficient between } 6 \text { - } \\
17 \%\end{array}$ \\
\hline Performance & Good & Good & Very good \\
\hline Availability & Not easily available & Readily available & Not easily available \\
\hline $\begin{array}{l}\text { Installation and } \\
\text { cost }\end{array}$ & $\begin{array}{l}\text { Not easily installed, high } \\
\text { initial installation cost but } \\
\text { mobile and immobile }\end{array}$ & $\begin{array}{l}\text { Easily installed, low } \\
\text { purchase cost but immobile. }\end{array}$ & $\begin{array}{l}\text { Not easily installed, high } \\
\text { initial installation cost but } \\
\text { mobile and immobile. }\end{array}$ \\
\hline $\begin{array}{l}\text { Effect on the } \\
\text { environment }\end{array}$ & $\begin{array}{l}\text { No side defect on } \\
\text { environment nor farmland } \\
\text { and livestock. }\end{array}$ & No side defect. & $\begin{array}{l}\text { Causes pollution both noise } \\
\text { and air pollution. Unpleasant } \\
\text { for farmlands and livestock. }\end{array}$ \\
\hline Renewability & $\begin{array}{l}\text { The all available sun, highly } \\
\text { renewable and inexhaustible }\end{array}$ & Non renewable & Non renewable \\
\hline $\begin{array}{l}\text { Power } \\
\text { consumption }\end{array}$ & $\begin{array}{l}\text { Very low consumption: as } \\
\text { low as } 0.373 \mathrm{kWh}\end{array}$ & $\begin{array}{l}\text { High power consumption } \\
\text { ranging between } 0.435- \\
1.12 \mathrm{kWh}\end{array}$ & $\begin{array}{l}\text { highest power consumption } \\
\text { ranging between } 0.222- \\
3.67 \mathrm{kWh}\end{array}$ \\
\hline
\end{tabular}

\subsection{CONCLUSION}

It can be concluded that the amount of water pumped at different time hours is not a function of the time nor the head since at all heads, there is equal amount of $30 \mathrm{~L}$ water pumped except the $5 \mathrm{~m}$ head with close amount of $25 \mathrm{~L}$.

After a careful analysis of the results obtained from the tests of the solar pump, with close visual observation of the performances of the diesel and electric pumps:

- the solar requires little or no maintenance when compared with the fuel and electrical pumps.

- $\quad$ The fuel pumps have the highest efficiency and best performance compared with the electrical and solar pumps.

- as its own advantage, the solar pump is the cleanest, environmentally friendly, has the least energy consumption and has the cheapest source of energy (the all - available sun).

A solar pump of equal power consumption with the diesel and electric pump will give a better output. Therefore, the solar pump should be harnessed in farms and rural areas having no access to national grid.

\section{REFERENCES}

[1] Prudhvitej Immadi, Nidhi Desai and Akhil Manepalli, 2015, “ Designing a Solar Water Pumping System"

[2] Osueke C.O., Uzendu, P., Ogbonna, I.D. 2013. Study and Evaluation of Solar Energy Variation in Nigeria. International Journal of Emerging Technology and Advanced Engineering. Volume 3, Issue 6.

[3] M.Abu-Aligah, 2011, "Design of Photovoltaic Water Pumping System and Compare it with Diesel Powered Pump", Jordan Journal of Mechanical and Industrial Engineering, Volume 5, Number 3.

[4] Balkeshwar Singh and Anil Kumar Mishra, 2015, "Utilization of Solar Energy for Driving a Water Pumping System". International Research Journal of Engineering and Technology (IRJET) Volume: 02.

[5] http://Savcosolarenergy.htm/water_pumping_system 2008.

[6] B. Eker, 2005, "Solar powered water pumping systems". Trakia journal of sciences, vol. 3, no. 7 .

[7] Suhagiya Falcon, Dave Siddharth, Seju Nirav, Patel Vashishtha and Diptesh Patel, 2015, "Development of Solar Powered Water Pumping System", International Journal for Innovative Research in Science \& Technology| Volume 1.

[8] Department of Agriculture, United States, 2010, "Design of Small Photovoltaic (PV) Solar-Powered Water Pump Systems", Technical Note No. 28.

[9] The Mathematics of Pumping Water. AECOM Design Build, Civil, Mechanical Engineering.

[10] Orji, J.O., Idusuyi, N., Aliu, T.O., Petinrin, M.O., Odejobi, O.A. and Adetunji. A.R., 2008. Utilization of Solar Energy for Power generation in Nigeria. International Journal of Energy Engineering. 2012, 2(2): 54-59 